\title{
Development of Teaching Aids Selection Standards in Maker Education
}

\author{
Woochun Jun* \\ Seoul National University of Education, Department of Computer Education, 06639, Korea
}

\begin{tabular}{l} 
A R T I C L E I N F O \\
\hline Article history: \\
Received: 30 May, 2019 \\
Accepted: 28 August, 2019 \\
Online: 24 September, 2019 \\
\hline Keywords: \\
Maker Education \\
Selection Standards \\
Teaching Aids \\
Physical Computing \\
\hline
\end{tabular}

\begin{abstract}
A B S T R A C T
Due to the recent development of information and communication technology, such as sensor technology, IoT technology, and smart technology, interest in maker education is increasing. Maker education offers students experience-based education that allows them to make their own results, giving them various interests and motivations. Recently, various research results on maker education have been under way. However, there is little research work on the teaching aids selection criteria for maker education. The purpose of this study is to justify the teaching aids selection standards that are developed in the previous research works. In the previous research work, 14 selection standards were developed in a total of eight areas. In this work, through rigorous statistical analysis, justification of the 14 standards are verified. The findings are expected to help a lot in future policy proposals and related research on maker education.
\end{abstract}

\section{Introduction}

This paper is an extension of work originally presented in ICTC2018[1].

Various changes are taking place throughout the industry following the recent advent of the $4^{\text {th }}$ industrial revolution era. Information-oriented industries are emerging at the forefront of the industry in the existing product-oriented manufacturing industry structure. The changes are prompting the acceleration of the modern knowledge and information society, calling for, among other things, interest in and understanding of the informationoriented society.

This change in the industrial structure also calls for many changes in public education in schools. In particular, interest in information education such as information collection, analysis, and processing is increasing in schools as the knowledge and information society accelerates. Information education is evolving into a software education form, especially from Information and Communication Technology Education, which started from 2000 in Korea. While the human image sought in ICT education was the core part of a computer-savvy user, the human image sought by the government in 2015 became the producer or manufacturer who could actually make software [2].

Maker education began in the early 2000s with the U.S. as the Do-It-Yourself Movement [3]. The DIY movement aimed to

"Corresponding Author: Woochun Jun, Seocho Dong, Seocho Gu, Seoul, Korea, wocjun@snue.ac.kr produce and use the necessary items in everyday life and also to share the necessary processes and products with each other. The DIY movement evolved into the Maker Movement, which, combined with the Maker Space, was ultimately born into Maker Education [4].

Meanwhile, according to [5], maker education was defined as follows by relating it to information education (or software education). In [5], maker education is a new type of educational paradigm to foster so-called "maker geeks" who can create things themselves. In other words, what students have imagined autonomously is produced directly using digital devices. It was also defined as process-oriented project education rather than the results that lead to the sharing of knowledge and experience learned in this process.

Maker education is in the spotlight as an experience-type education that can increase students' interest and motivation for learning. It is also receiving attention at the schools in a typical form of convergence education, combined with various subjects, such as science and practical subjects. In addition, various forms of hands-on exhibitions and contests are attracting interest from students and parents, and teachers are given various training opportunities to encourage interest in maker education.

Along with the spread of maker education, academic research is under way on various maker education. However, in order to carry out actual maker education on the schools, there is a lack of standards on how to choose teaching aids, which is the core of the maker education, among other things Generally, teaching aids are 


\section{W. Jun / Advances in Science, Technology and Engineering Systems Journal Vol. 4, No. 5, 139-142 (2019)}

tools used in class activity. The typical teaching aids in class are scissors, colored paper, glue, and so on. In maker education, the typical teaching aids includes 3D printers, 3D pens, cutting tool, sewing machine, and so on. Teaching aids are either raw materials or making tools like a machine tool. In maker education, teaching aids are essential for class activity. Thus, choosing right teaching aids in maker education is very important in successful class.

The purpose of this study is to justify teaching aids selection standards that are developed in the previous research works. That is, for those 14 selection standards, rigorous statistical work is done and selection standards are proved to be useful in schools.

The rest of this paper is as follows. First, in Chapter 2,related works are presented. In Chapter 3, the existing 14 selection standards are introduced. In Chapter 4, statistical analysis is presented for selection standards. Finally, in Chapter 5, conclusions and further research issues will bediscussed.

\section{Related Works}

This chapter presents an overall relevant study of maker education. First, the typical characteristics of maker education can be summarized as follows [6].

First, knowledge can be organized through interaction with objects or people through direct-creating activities. In addition, outputs created directly by learners can induce social participation through various sharing, thereby providing a meeting place for various participants to communicate together through common tasks.

Second, it can provide self-directed and cooperative learning. Makers are engaged in maker activities, choosing their own themes from areas of personal interest and social issues. In addition, working on cooperative projects can lead to mutual respect and communication through cooperative learning.

Third, it provides an environment for making activities. In other words, the maker education will require a maker space for direct production activities and a variety of teaching aids and materials. The maker space needs an environment with the tools needed for the maker's activities.

Fourth, maker education requires a position as an inventor and creator as a learner. In other words, students go through the process of choosing their own themes through making activities. Through this process, learners experience creative problemsolving.

Fifth, in maker education, a teacher will act as a helper. Maker activities are basically activities that can improve students' creative thinking and problem-solving skills. In addition, since students decide on their own topics, tools, methods, etc., they should provide a free learning environment and a free environment for evaluation regardless of the outcome's success or failure. Therefore, a teacher's role should be a learning guideor facilitator.

Sixth, students can start with personal participation in maker education and continue with social participation. This is because the maker education can share and open information with other learners through personal problem solving, starting from social issues and creating experiences, and to see if personal and social problems can be solved through product sharing.

On the other hand, a recent study by [7] developed and presented a measure of the ability of making as part of the software coding- based maker education program for scientific gifted children. The Matching Capacity Scale means the competency that students who participate in the maker education should have, and the makeup competency measures presented in [7] are as follows. Overall, the making capabilities comprise three core competences: analysis capabilities, design capabilities, and implementation capabilities. Specifically, analysis capability refers to the ability to collect data and analyze problems, and design capability corresponds to the ability to generate and refine ideas for problem resolution, and to come up with solutions through sharing ideas. Finally, implementation capability refers to the ability to select a tool for problem solving, generate results through active participation and evaluate results. The three core competences were divided into more detailed sections to provide specific capabilities.

Table 1. The Original Selection Standards

\begin{tabular}{|c|c|c|}
\hline Number & Standard & Detailed Criteria \\
\hline 1 & Safety & $\begin{array}{l}\text {-There should be no risk of safety } \\
\text { accidents. } \\
\text {-Material that can be harmful to } \\
\text { health should not be used }\end{array}$ \\
\hline 2 & $\begin{array}{l}\text { Subject } \\
\text { Compatibility }\end{array}$ & $\begin{array}{l}\text {-It should be available for various } \\
\text { educational } \\
\text { activities } \\
\text {-It should be possible to integrate } \\
\text { with other teaching materials and } \\
\text { learning materials. }\end{array}$ \\
\hline 3 & Multi-purpose & $\begin{array}{l}\text {-The teaching aids must support } \\
\text { various functions through the } \\
\text { connection of built-in or additional } \\
\text { parts. }\end{array}$ \\
\hline 4 & $\begin{array}{l}\text { Ease of } \\
\text { Manipulation }\end{array}$ & $\begin{array}{l}\text {-(Teacher) It should be easy to use } \\
\text { in class by simple training. } \\
\text {-(Student) It should be easy to use } \\
\text { after simple teaching and learning } \\
\text { about how to use. }\end{array}$ \\
\hline 5 & Economics & $\begin{array}{l}\text {-It should be easy to buy within } \\
\text { budget items of the school. } \\
\text {-Parts can be easily procured within } \\
\text { reasonable time and price. }\end{array}$ \\
\hline 6 & $\begin{array}{l}\text { Universal } \\
\text { Design }\end{array}$ & $\begin{array}{l}\text {-It should be designed for the older, } \\
\text { people with mental and physical } \\
\text { disabilities. } \\
\text {-It should provide alternative } \\
\text { functions for main functions }\end{array}$ \\
\hline 7 & $\begin{array}{l}\text { Gender } \\
\text { Equality }\end{array}$ & $\begin{array}{l}\text {-It should be used regardless of } \\
\text { gender. }\end{array}$ \\
\hline 8 & Durability & $\begin{array}{l}\text {-Failure or breakage should not } \\
\text { occur even if students repeatedly } \\
\text { use. } \\
\text {-It should be able to withstand the } \\
\text { minor impact (collision, drop, etc.) } \\
\text { that occurs between educational } \\
\text { activities. }\end{array}$ \\
\hline
\end{tabular}

\section{Development of Teaching Aids Selection Standards}

\subsection{Design Principles}

The selection standards for teaching aids in maker education are developed through the following principles [1]. 


\section{W. Jun / Advances in Science, Technology and Engineering Systems Journal Vol. 4, No. 5, 139-142 (2019)}

First, it is in line with the general teaching aids selection criteria used in primary and secondary schools. That is because the teaching aids used in maker education are essentially one of the teaching aids.

Second, it is based on the selection criteria for the physical computing education, which is mainly used in recent software education.

Third, the universal design principle is adopted so that it can be used by anyone. In other words, care is taken to make it easier for anyone, regardless of age, gender, age, ordisability.

\subsection{The Original Selection Standards}

In [1], the original selection standards of teaching aids in maker education are proposed. The following table 1 show the initial standards.

\section{Statistical Analysis}

\subsection{Design of Analysis}

Verification of the reliability of the tool to measure the importance of teaching aids selection standards in maker education showed that Cronbach $\alpha$ was 0.77 and was reliable, as shown in Table 2.

Table 2. Reliability of Measurement Tool

\begin{tabular}{|c|c|}
\hline Item Number & Cronbach's $\alpha$ \\
\hline 14 & 0.77 \\
\hline
\end{tabular}

The data gathered in this work were analyzed using the Statistical Package for the Social Science (SPSS) WIN 25.0 program. Cronbach $\alpha$ is used to verify the reliability of the measuring tool. In addition, the average and standard deviation were calculated in order to find out the importance of the selection standards in maker education, and the correlation analysis was conducted to understand the relationship between the sub-areas of selection standards and selection standard in maker education.

\subsection{Analysis Results}

\section{-Descriptive Statistics}

The average and standard deviation of questions asked about the importance of teaching aids selection standards in maker education are as shown in Table 3.

\subsection{Sub-area of Descriptive Statistics}

According to the results of the review of the average and standard deviation in the sub-areas of teaching aids selection standards in maker education are shown in table 4 . The average importance of the selection standards for the teaching aids in maker education was 4.13 , and the selection standards for the teaching aids were important.

Among the sub-areas of the standards for selection standards for teaching aids, "safety" 4.84, followed by "ease of manipulation" 4.52, "durability" 4.30, "economics" 4.28, "subject compatibility" 4.05, "gender equality" 4.00 and "multi-purpose" 3.78 , with the lowest "universal design."
As above, it is shown that "safety" is the highest in the subareas of the teaching aids selection standards in maker education, and that "universal design" is less important than other areas.

Table 3. Results of Descriptive Statistics

\begin{tabular}{|c|c|c|}
\hline Standard & AVG & SD \\
\hline $\begin{array}{l}\text { 1. There should be no risk of safety } \\
\text { accidents. }\end{array}$ & 4.84 & 0.37 \\
\hline $\begin{array}{l}\text { 2. Material that can be harmful to health } \\
\text { should not be used. }\end{array}$ & 4.84 & 0.37 \\
\hline $\begin{array}{l}\text { 3. It should be available for various } \\
\text { educational activities }\end{array}$ & 4.13 & 0.91 \\
\hline $\begin{array}{l}\text { 4. It should be possible to integrate with } \\
\text { other teaching materials and learning } \\
\text { materials. }\end{array}$ & 3.97 & 0.82 \\
\hline $\begin{array}{l}\text { 5. The teaching aids must support } \\
\text { various functions through the } \\
\text { connection of built-in or additional } \\
\text { parts. }\end{array}$ & 3.78 & 0.94 \\
\hline $\begin{array}{l}\text { 6. (Teacher) It should be easy to use in } \\
\text { class by simple training. }\end{array}$ & 4.41 & 0.80 \\
\hline $\begin{array}{l}\text { 7. (Student) It should be easy to use after } \\
\text { simple teaching and learning about how } \\
\text { to use. }\end{array}$ & 4.63 & 0.61 \\
\hline $\begin{array}{l}\text { 8. It should be easy to buy within budget } \\
\text { items of the school. }\end{array}$ & 4.38 & 0.66 \\
\hline $\begin{array}{l}\text { 9. Parts can be easily procured within } \\
\text { reasonable time and price. }\end{array}$ & 4.19 & 0.86 \\
\hline $\begin{array}{l}\text { 10. It should be designed for the older, } \\
\text { people with mental and physical } \\
\text { disabilities. }\end{array}$ & 3.06 & 1.16 \\
\hline $\begin{array}{l}\text { 11. It should provide alternative } \\
\text { functions for main functions }\end{array}$ & 3.00 & 1.14 \\
\hline $\begin{array}{l}\text { 12. It should be used regardless of } \\
\text { gender. }\end{array}$ & 4.00 & 1.19 \\
\hline $\begin{array}{l}\text { 13. Failure or breakage should not occur } \\
\text { even if students repeatedly use. }\end{array}$ & 4.28 & 0.85 \\
\hline $\begin{array}{l}\text { 14. It should be able to withstand the } \\
\text { minor impact (collision, drop, etc.) that } \\
\text { occurs between educational activities. }\end{array}$ & 4.31 & 0.69 \\
\hline
\end{tabular}

Where AVG and SD stand for average and standard deviation, respectively.

\subsection{Correlation Analysis}

The results of a review of the correlation between the sub-areas of the standards for teaching aids selection standards in maker education and the whole teaching aids selection standards in maker education are shown in Table 5.

Safety $(\mathrm{r}=.455 ; \mathrm{p}<.01)$ and subject compatibility $(\mathrm{r}=.627$, $\mathrm{p}<.001)$, multi-purpose $(\mathrm{r}=.548, \mathrm{p}<.01)$, ease of manipulation $(\mathrm{r}=.391, \mathrm{p}<.05)$, economics $(\mathrm{r}=.534, \mathrm{p}<.01)$, universal design $(\mathrm{r}=.725, \mathrm{p}<.001)$, gender equality $(\mathrm{r}=.824, \mathrm{p}<.001)$, and durability $(\mathrm{r}=.453, \mathrm{p}<.01)$ showed a statistically significant static correlation with the importance of the standards for teaching aids selection 


\section{W. Jun / Advances in Science, Technology and Engineering Systems Journal Vol. 4, No. 5, 139-142 (2019)}

standards in maker education. Therefore, the higher importance of safety and subject compatibility, multi-purpose, ease of manipulation, economics, universal design, gender equality, and durability of the standards for teaching aids selection standards in maker education, the higher importance of the standards for teaching aids selection standards in maker education.

Table 4. Results of Descriptive Statistics of Sub-area

\begin{tabular}{|l|l|l|}
\hline Evaluation Standard Area & AVG. & SD \\
\hline Safety & 4.84 & 0.27 \\
\hline Subject Compatibility & 4.05 & 0.73 \\
\hline Multi-purpose & 3.78 & 0.94 \\
\hline Ease of Manipulation & 4.52 & 0.63 \\
\hline Economics & 4.28 & 0.61 \\
\hline Universal Design & 3.03 & 1.07 \\
\hline Gender Equality & 4.00 & 1.19 \\
\hline Durability & 4.30 & 0.69 \\
\hline Overall Selection Standards & 4.13 & 0.43 \\
\hline
\end{tabular}

where AVG and SD stand for average and standard deviation, respectively.

Table 5. Results of Correlation Analysis

\begin{tabular}{|l|l|}
\hline \multicolumn{1}{|c|}{ Area } & Correlation Value \\
\hline Safety & $0.455^{* *}(0.009)$ \\
\hline Subject Compatibility & $0.627^{* * *}(0.000)$ \\
\hline Multi-purpose & $0.548^{* *}(0.001)$ \\
\hline Ease of Manipulation & $0.391^{*}(0.027)$ \\
\hline Economics & $0.534^{* *}(0.002)$ \\
\hline Universal Design & $0.725^{* * *}(0.000)$ \\
\hline Gender Equality & $0.824^{* * *}(0.000)$ \\
\hline Durability & $0.453^{* *}(0.009)$ \\
\hline \\
Where $* \mathrm{p}<.05, * * \mathrm{p}<.01, * * * \mathrm{p}<.001$
\end{tabular}

\section{Conclusions and Further Research Issues}

Along with the development of various information and communication technologies and smart technologies, maker education is receiving attention at schools due to the increase in the number of available teaching aids at schools. Maker education is an experience-based education in which students directly participate in designing and analyzing the work they want to produce, and finally participate in production, which has the advantage of generating interest and motivation for students. Maker education is also very popular as a project-oriented cooperative study because teachers and students can participate and discuss the entire process of producing works together.

The role of the teaching aids in maker education is very important and the interest and academic performance of students in the whole class, depending on how they choose the teaching aids, also affects safety issues. However, there has been no standardized research or guideline on the standards for teaching aids selection standards in maker education.

The purpose of this study is to justify the teaching aids selection standards that are developed and proposed. In the previous research, 14 selection standards are developed and analyzed statistically. In this research, with more rigorous statistical analysis, the justification of the results is verified.

The immediate further research issues are as follows. At first, it is necessary to present more detailed selection standards depending on tools of maker education such as 3D printer. Also, it is also necessary to present more integrated and extensive selection standards for both maker education and software education. This is because there is no clear limit between maker education and software education.

\section{Conflict of Interest}

The authors declare no conflict of interest.

\section{References}

[1] W. C. Jun, "A Study on Development of Selection Standards of Maker Education Teaching Aids" in 2018 International Conference on Information and Communication Technology Convergence, Jeju Island, Korea, 2018.

http://10.1109/ICTC.2018.8539704

[2] Korea Ministry of Education, "Software Education Training and Operation Guidelines", 2015.

[3] E. R. Halverson, and E. M. Sheridan, "The Maker Movement in Education”, Harvard Business Review, 84(4), 495-504, 2014. https://doi.org/10.17763/haer.84.4.34j1g68140382063

[4] D. Dougherty, "The Maker Movement, Innovations: Technology, Governance, Globalization“, MIT Press, 7(3), .11-14, 2012. https://doi.org/10.1162/INOV_a_00135

[5] Seoul Metropolitan Office of Education, "'2018 '2022 Mid and Longterm Maker Education Development Master Plan", November 1, 2017.

[6] M. J. Kang, "Development of Checklist for Development and Operation of Maker Education Program", Master Thesis, Kyunghee University, 2018

[7] J. H. Lee and J. H. Jang, “ Development of Maker Education Program based on Software Coding for the Science Gifted", Journal of Gifted/Talented Education, 27(3) 331-348, 2017.

http://doi.org//10.9722/JGTE.2017.27.331 